\title{
Penman-Monteith with missing data and Hargreaves-Samani for ETo estimation in Espírito Santo state, Brazil
}

\author{
Luan P. Venancio ${ }^{1}$, Fernando F. da Cunha ${ }^{1}$, Everardo C. Mantovani ${ }^{1}$, \\ Gilberto C. Sediyama ${ }^{1}$, Fernando C. Eugenio ${ }^{2} \&$ Catariny C. Aleman ${ }^{1}$

\begin{abstract}
${ }^{1}$ Universidade Federal de Viçosa/Departamento de Engenharia Agrícola. Viçosa, MG, Brasil. E-mail: luan.venancio@ufv.br (Corresponding author) - ORCID: ORCID: 0000-0002-5772-7118; catariny@ufv.br - ORCID: 0000-0002-3894-3077

${ }^{2}$ Universidade Federal de Santa Maria/Coordenadoria Acadêmica de Cachoeira do Sul. Cachoeira do Sul, RS , Brasil. E_mail: fernando.eugenio@ufsm.br -
\end{abstract} \\ 0000-0002-5544-8588; fernando.cunha@ufv.br - ORCID: 0000-0002-1671-1021; evarardo@ufv.br - ORCID: 0000-0002-8795-8793; g.sediyama@ufv.br - \\ ORCID: 0000-0002-1148-1167
}

\begin{abstract}
The Penman-Monteith method (PM-FAO) is recommended as standard for calculation of reference evapotranspiration (ETo). However, its use requires a series of meteorological variables that is not normally available, restricting its application in many locations. A solution to the problem of unavailability of meteorological data was presented in FAO Bulletin 56, which contains methodologies for estimating wind speed, solar radiation and relative humidity. The objective of the present study was to evaluate the performance of the PM-FAO methodologies for missing data and Hargreaves-Samani as alternatives to the PM-FAO standard method at different time scales and seasons for the municipalities of Linhares and São Mateus, located in the northern region of the state of Espírito Santo. The comparison was performed using linear regression parameters $\left(\beta_{0}\right.$ and $\left.\beta_{1}\right)$, coefficient of determination, standard error of estimation (SEE) and coefficient of performance. The best alternative to the standard PM-FAO standard method for estimating ETo in the studied area was the Penman-Monteith method with missing wind speed data, since the $\mathrm{R}^{2}$ for this method always remained above 0.94 and the confidence coefficient was classified as great, for all seasons and scales. The Hargreaves-Samani method did not present satisfactory performance, with $\mathrm{R}^{2}$ below 0.7 , regardless of the time scale and time of the year, and it yielded the greatest SEE $\left(1.0 \mathrm{~mm} \mathrm{~d}^{-1}\right)$ at spring on a two-day scale. Thus, its use in the northern region of the Espírito Santo state is not recommended.
\end{abstract}

Key words: data scarcity, time scale, seasons

\section{Penman-Monteith com dados faltantes e Hargreaves-Samani para estimativa da ETo no estado do Espírito Santo, Brasil}

RESUMO: O método de Penman-Monteith (PM-FAO) é recomendado como padrão para cálculo da evapotranspiração de referência (ETo). Contudo, a sua utilização requer uma série de variáveis meteorológicas que normalmente não estão disponíveis, restringindo sua aplicação em muitos locais. Uma solução para o problema de indisponibilidade de dados meteorológicos, foi apresentado no boletim no 56 da FAO, o qual contém metodologias para estimar velocidade do vento, radiação solar e umidade relativa. O objetivo do presente estudo foi avaliar o desempenho das metodologias PM-FAO para dados faltantes e Hargreaves-Samani como alternativas ao método PM-FAO em diferentes escalas de tempo e estações do ano para as cidades de Linhares e São Mateus, localizadas na região norte do estado do Espírito Santo. A comparação foi realizada utilizando os parâmetros da regressão linear $\left(\beta_{0} \mathrm{e} \beta_{1}\right)$, coeficiente de determinação, erro padrão de estimativa (SEE) e coeficiente de desempenho. A melhor alternativa ao método padrão, PM-FAO, para estimativa de ETo na área de estudo é o método de Penman-Monteith com dados faltantes de velocidade do vento, uma vez que o $\mathrm{R}^{2}$ para este método foi sempre superior 0,94 e o coeficiente de desempenho classificado como ótimo, para todas as estações e escalas de tempo. O método de Hargreaves-Samani não apresentou desempenho satisfatório, com $\mathrm{R}^{2}$ abaixo de 0,7 independente da escala de tempo e da época do ano e, produziu o maior $\operatorname{SEE}\left(1,0 \mathrm{~mm} \mathrm{~d}^{-1}\right)$ na primavera na escala de dois dias. Assim, o seu uso na região norte do estado do Espírito Santo não é recomendado.

Palavras-chave: escassez de dados, escala de tempo, estações do ano 


\section{INTRODUCTION}

The Penman-Monteith method (PM-FAO) is recommended as the standard method for estimates of ETo (Allen et al., 1998). The PM-FAO equation presents two advantages over dozens of other equations for this purpose. The first is that the PM-FAO equation can be used globally without local calibrations because of its physical basis, and second, it is a well-documented equation that has been tested using a large number of lysimeters (Gocic \& Trajkovic, 2010). However, it presents a negative point, which is the requirement of a broad set of meteorological data, precluding its use in places that do not have automatic meteorological stations that collect all the data necessary for its application.

In places where there is a network of meteorological stations, such as those of the Instituto Nacional de Meteorologia - INMET, it is recommended to use the PM-FAO method. In places like the Northern region of Espírito Santo state, where most farmers do not have access to automatic meteorological stations, alternative methods should be studied and made available.

Two important alternatives to the original PM-FAO equation are the use of the PM-FAO equation itself with estimated missing data, as proposed by Allen et al. (1998), and the Hargreaves \& Samani (1985) equation, due to its great usefulness, since it requires only meteorological data of maximum and minimum air temperatures. Several studies have been focused on comparing these two approaches to the original PM-FAO method (Gocic \& Trajkovic, 2010; Sentelhas et al., 2010; Cunha et al., 2017).

Therefore, this study aimed to evaluate the performance of the PM-FAO methodologies for missing data and Hargreaves \& Samani (1985) as alternatives to the FAO PenmanMonteith method at different time scales and seasons for the municipalities of Linhares and São Mateus, located in the Northern region of the state of Espírito Santo, Brazil.

\section{Material AND Methods}

The meteorological data needed to carry out this study were obtained from the INMET and come from automatic meteorological stations located in the municipalities of Linhares and São Mateus, Northern region of the state of Espírito Santo (Table 1). According to the Köppen classification (Alvares et al., 2013), the climate of region is of the type "Aw", tropical, with rainy season in the summer and dry winter.

The meteorological data used in the study were: average, maximum and minimum air temperature $\left({ }^{\circ} \mathrm{C}\right)$; average, maximum and minimum relative humidity (\%); average and maximum dew point temperature $\left({ }^{\circ} \mathrm{C}\right)$; wind speed at $10 \mathrm{~m}$ height $\left(\mathrm{m} \mathrm{s}^{-1}\right)$ and global radiation $\left(\mathrm{kJ} \mathrm{m}^{-2} \mathrm{~d}^{-1}\right)$. Wind speed was corrected for height of $2 \mathrm{~m}$ by multiplying the value by the coefficient 0.7480, according to Allen et al. (1998).
Six different methodologies were used to estimate ETo. The first was Penman-Monteith (PM-FAO) with complete meteorological data (Allen et al., 1998) used as a reference in the present study (Eq. 1). The second was PM-FAO with missing data of relative humidity, which was obtained by means of the relationship between the partial and saturation vapor pressures (Eq. 2), according to Allen et al. (1998).

$$
\begin{gathered}
\mathrm{ET}_{\mathrm{o}}=\frac{0.408 \Delta\left(\mathrm{R}_{\mathrm{n}}-\mathrm{G}\right)+\gamma \frac{900}{\mathrm{~T}+273} \mathrm{u}_{2}\left(\mathrm{e}_{\mathrm{s}}-\mathrm{e}_{\mathrm{a}}\right)}{\Delta+\gamma\left(1+0.34 \mathrm{u}_{2}\right)} \\
\mathrm{e}_{\mathrm{a}}=0.6108 \exp \left[\frac{17.27+\mathrm{T}_{\min }}{\mathrm{T}_{\text {min }}+273.3}\right]
\end{gathered}
$$

where:

ETo - reference evapotranspiration, $\mathrm{mm} \mathrm{d}^{-1}$;

$R_{n} \quad$ - net radiation on the surface of the crop, $M J m^{-2} d^{-1}$;

$\mathrm{G} \quad$ - soil heat flux density, $\mathrm{MJ} \mathrm{m}^{-2} \mathrm{~d}^{-1}$;

$\mathrm{T} \quad$ - average daily air temperature at $2 \mathrm{~m}$ height, ${ }^{\circ} \mathrm{C}$;

$\mathrm{u}_{2} \quad$ - wind speed at $2 \mathrm{~m}$ height, $\mathrm{m} \mathrm{s}^{-1}$;

$\mathrm{e}_{\mathrm{s}} \quad$ - saturation vapor pressure, $\mathrm{kPa}$;

$\mathrm{e}_{\mathrm{a}} \quad$ - partial vapor pressure, $\mathrm{kPa}$;

$\Delta \quad$ - slope of the saturation vapor pressure curve, $\mathrm{kPa}^{\circ} \mathrm{C}^{-1}$;

$\gamma \quad$ - psychrometric coefficient, $\mathrm{kPa}^{\circ} \mathrm{C}^{-1}$; and,

$\mathrm{T}_{\min }$ - minimum air temperature, ${ }^{\circ} \mathrm{C}$.

The third methodology was PM-FAO with missing data of wind speed, which was estimated with the daily mean values for period studied: 2.10 and $1.96 \mathrm{~m} \mathrm{~s}^{-1}$ for Linhares and São Mateus stations, respectively. The fourth option evaluated was PM-FAO with missing data of solar radiation and replaced with data estimated by means of the air temperature (Eq. 3), following the recommendations of Allen et al. (1998).

$$
\mathrm{R}_{\mathrm{S}}=0.16\left(\mathrm{~T}_{\max }-\mathrm{T}_{\min }\right)^{0.5} \mathrm{R}_{\mathrm{a}}
$$

where:

$\mathrm{R}_{\mathrm{S}} \quad$ - solar radiation, $\mathrm{MJ} \mathrm{m}^{-2} \mathrm{~d}^{-1}$;

$\mathrm{T}_{\max }$ - maximum air temperature; ${ }^{\circ} \mathrm{C}$;

$\mathrm{T}_{\min }$ - minimum air temperature, ${ }^{\circ} \mathrm{C}$; and,

$\mathrm{R}_{\mathrm{a}}$ - extraterrestrial radiation, $\mathrm{MJ} \mathrm{m}^{-2} \mathrm{~d}^{-1}$.

The fifth, PM-FAO with missing data of solar radiation and replaced with data estimated by local extraterrestrial radiation and solar radiation from a nearby meteorological station (Eq. 4), according to Allen et al. (1998). And the last, the original equation of Hargreaves \& Samani (1985), Eq. 5.

$$
\mathrm{R}_{\mathrm{S}}=\frac{\mathrm{R}_{\mathrm{S}}, \mathrm{reg}}{\mathrm{R}_{\mathrm{a}}, \mathrm{reg}} \mathrm{Ra}
$$

\begin{tabular}{|c|c|c|c|c|c|}
\hline Code & Location & Latitude & Longitude & Altitude (m) & Data period \\
\hline OMM - 86805 & Linhares & $-19.3569^{\circ}$ & $-40.0686^{\circ}$ & 38 & 0ct/2006 - Feb/2015 \\
\hline OMM - 86786 & São Mateus & $-18.6761^{\circ}$ & $-39.8640^{\circ}$ & 29 & Oct/2006 - Feb/2015 \\
\hline
\end{tabular}

Table 1. Information regarding the meteorological stations 
where:

$\mathrm{R}_{\mathrm{S}} \quad$ - solar radiation from São Mateus station, $\mathrm{MJ} \mathrm{m} \mathrm{m}^{-2} \mathrm{~d}^{-1}$; $\mathrm{R}_{\mathrm{S}}$, reg - solar radiation from Linhares station, $M J \mathrm{~m}^{-2} \mathrm{~d}^{-1}$;

$\mathrm{R}_{\mathrm{a}}$, reg - radiation at the top of the atmosphere for Linhares station, $\mathrm{MJ} \mathrm{m}^{-2} \mathrm{~d}^{-1}$; and,

$\mathrm{Ra}$ - radiation at the top of the atmosphere for São Mateus

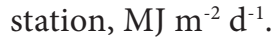

$$
\mathrm{ET}_{0}=0.0023(\mathrm{~T}+17.8)\left(\mathrm{T}_{\max }-\mathrm{T}_{\min }\right)^{0.5} \mathrm{R}_{\mathrm{a}}
$$

where:

$\mathrm{T} \quad$ - average daily air temperature, ${ }^{\circ} \mathrm{C}$;

$\mathrm{T}_{\max }$ - maximum daily temperature, ${ }^{\circ} \mathrm{C}$;

$\mathrm{T}_{\min }$ - minimum daily temperature, ${ }^{\circ} \mathrm{C}$; and,

$\mathrm{R}_{\mathrm{a}} \quad$ - extraterrestrial solar radiation, $\mathrm{mm} \mathrm{d}^{-1}$.

The ETo data obtained through the different methodologies were compared with the data obtained by the PM-FAO method at one-, two-, four- and seven-day intervals. In order to obtain ETo values at intervals of two, four and seven days a moving average was used. The final amount of data was the same at all scales. It was decided to compare ETo estimates only within the same climatic season. The performance of the methods in relation to the PM-FAO method was analyzed by comparing the linear regression parameters $\beta_{0}$ and $\beta_{1}$, coefficient of determination $\left(\mathrm{R}^{2}\right)$, standard error of estimation (SEE) and confidence coefficient (c) (Camargo \& Sentelhas, 1997).

\section{Results AND Discussion}

The PM-FAO method with missing data of wind speed (PM-FAO missing $\mathrm{U}_{2}$ ) at daily scale was the best alternative compared to PM-FAO standard method, with $\mathrm{R}^{2}$ values of 0.96 for spring and summer seasons and 0.94 in the autumn and winter (Figure 1). The good fit of this method was also observed by the regression coefficients of the equations, that
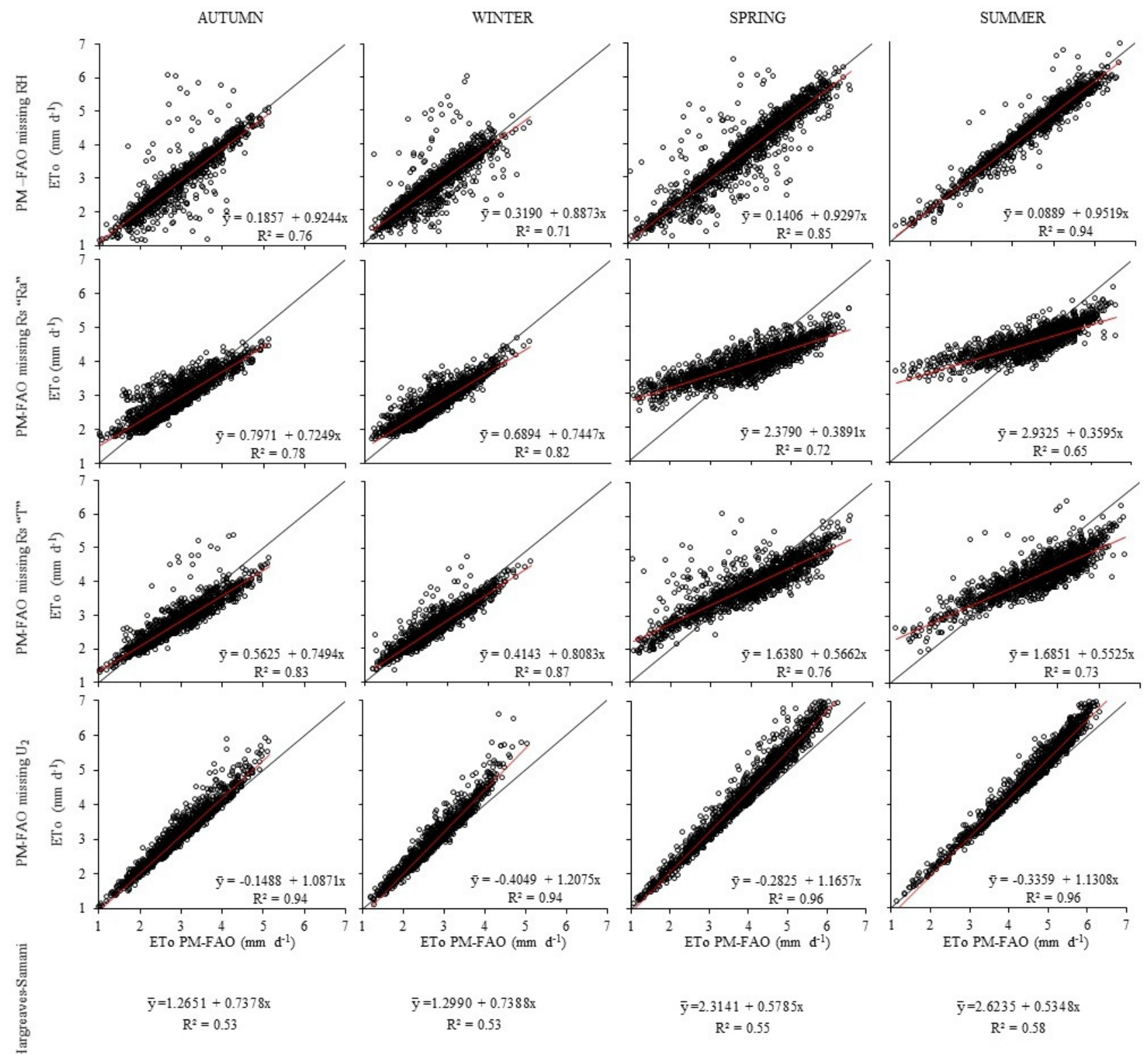

PM-FAO missing Rs "Ra" means PM-FAO with missing data of solar radiation (Rs) estimated with extraterrestrial solar radiation (Ra) and PM-FA0 missing Rs "T" means PM-FA0 with missing data of solar radiation (Rs) estimated with air temperature data

Figure 1. Values of reference evapotranspiration (ETo) obtained from PM-FAO method compared to the values obtained from PM-FAO method calculated with missing data and Hargreaves-Samani at daily time scale for different seasons of the year 
is, $\beta_{0}$ with values close to zero (0) and $\beta_{1}$ close to one (1.0). Since anemometers have high costs in a climatological station, acquiring simpler equipment (without this sensor) will allow ETo estimates to be accurate and cost-effective.

It is important to point out that the PM-FAO method, despite being an approach recommended by FAO and world reference, it is still an estimation method and subject to errors. The best way to indicate alternative methods is to compare them to results obtained in lysimeters.

Another important point is that climatological station sensors are exposed to the varied conditions in the field and subject to problems. An anemometer failure will not prevent the use of the mean value and does not strongly affect the value of ETo.

The values of $\beta_{0}$ were negative for PM-FAO missing data of $\mathrm{U}_{2}$. The methodology tends to underestimate the ETo when PM-FAO shows values close to zero. However, since the fit for the missing variable was great $\left(\mathrm{R}^{2} \geq 0.94\right)$, the underestimates were very small. The optimal performance of PM-FAO with the lack of $\mathrm{U}_{2}$ data was also obtained by other authors (Sentelhas et al., 2010; Alencar et al., 2015; Cunha et al., 2017).

As far as climate stations are concerned, the PM-FAO with missing data of RH (PM-FAO missing $\mathrm{RH}$ ) for summer is the second best option compared to the PM-FAO $\left(\mathrm{R}^{2}=0.94\right)$. For winter and autumn, the results were less satisfactory (Figure 1). In these seasons of the year, the $\mathrm{RH}$ presents higher values in comparison to the spring and summer, so a greater influence on the ETo values. PM-FAO with missing RH data, although not as efficient as missing $\mathrm{U}_{2}$ data, did not tend to underestimate and overestimate in the range analyzed, based on the 1:1 line.

The performance of PM-FAO missing Rs "Ra", which means the use of PM-FAO with missing data of solar radiation (Rs) estimated with extraterrestrial solar radiation ( $\mathrm{Ra})$, was not satisfactory in summer $\left(\mathrm{R}^{2}=0.65\right)$, followed by spring and autumn (Figure 1). A better performance was observed in winter $\left(\mathrm{R}^{2}=0.82\right)$. During the coldest seasons of the year (winter and autumn), relative humidity and wind have a greater effect on ETo. On the other hand, the absence of radiation and temperature in the estimates has a lower effect, which justifies better results for these seasons.

When the lack of Rs replaced with estimated air temperature (PM-FAO missing Rs "T") is evaluated, the behavior is similar to the previous one, due to high positive correlation between temperature and solar radiation (Figure 1). However, it is worth noting that there is an expressive performance gain in relation to the PM-FAO missing Rs "Ra" methodology, mainly in the summer. Both alternatives for missing solar radiation data present overestimates below $4 \mathrm{~mm} \mathrm{~d}^{-1}$ and underestimates above this value, in the spring and summer (Figure 1).

The estimation of solar radiation (Rs) in the spring and summer seasons by means of global solar radiation $\left(R^{2}=0.72\right.$ and 0.65$)$ or air temperature $\left(\mathrm{R}^{2}=0.76\right.$ and 0.73$)$, respectively, and its subsequent use in the estimation of ETo leads to the worse estimation results among the missing data options. On the other hand, during autumn and winter seasons, the absence of $\mathrm{RH}$ leads to worst results based on the $\mathrm{R}^{2}$ ( 0.76 and 0.71 for the autumn and winter, respectively).
These results can be explained by the great influence of solar radiation on ETo estimates in relation to the other variables, as already verified in several studies (Lemos Filho et al., 2010; Silva et al., 2011; Hou et al., 2013). Some studies have indicated that the decreasing order of influence on ETo estimates are: solar radiation, air temperature, relative humidity and wind speed, with some variation of position between the last three depending on the climate of the region.

The Hargreaves-Samani method (HS) presented the worst estimates of ETo among the options studied (Figure 1), based on the low values of $\mathrm{R}^{2}$. In addition, the HS method overestimates ETo in practically all seasons to values below $5 \mathrm{~mm} \mathrm{~d}^{-1}$, which can also be confirmed by the high values of $\beta_{0}$.

Despite the unsatisfactory fits, it is worth noting that summer is the period when the method is more efficient, especially for estimates above $5 \mathrm{~mm} \mathrm{~d}^{-1}$. This is because the empirical method of HS was designed for use in semi-arid conditions (Hargreaves \& Samani 1985). The summer period of the studied region is the season that most resembles this condition.

The HS method, despite providing the worst estimates, is a method that can be easily calibrated from the PM-FAO method in order to improve its ETo estimates. If this calibration improves performance, an efficient and easy-to-use method is available. This calibration has been done by several researchers in many regions of Brazil: Goiás (Fernandes et al., 2012), Ceará (Lima Júnior et al., 2016), Pernambuco (Arraes et al., 2016) and Sete Lagoas - MG (Borges Júnior et al., 2017) and, of the world: Spain (Gavilán et al., 2006), Iran (Tabari \& Zalaee, 2011), Bosnia and Herzegovina (Čadro et al., 2017) and SichuanChina (Feng et al., 2017).

The determination of ETo at scales greater than one day is important in studies of climate change, in irrigation management, for determination of evapotranspiration for design purposes, etc. The PM-FAO method with missing data of $\mathrm{U}_{2}$ was superior to the other options based on $\mathrm{R}^{2}$, regardless of the time scale and the season (Table 2), which was also found on a daily scale.

For PM-FAO with missing $\mathrm{RH}$ data, there were no improvements with increasing time scale in the summer, with $\mathrm{R}^{2}$ remaining at 0.94 for all scales. However, in the autumn and winter seasons, performance was reliable, especially on the 7 -day autumn scale $\left(\mathrm{R}^{2}=0.9\right)$ and the coefficient " $\beta_{0}$ ” closer to zero and " $\beta$ " close to one.

PM-FAO missing Rs "Ra" did not improve its performance in the summer, for any time scale (Table 2). In autumn and winter, the improvement was good, with $\mathrm{R}^{2}$ increasing by $10 \%$ compared to the seven-day and one-day scales. In addition, improvement in the regression coefficient values was observed. PM-FAO missing Rs " $\mathrm{T}$ ” behaved very closely to PM-FAO missing Rs "Ra”, highlighting only a slightly better performance (higher $\mathrm{R}^{2}$ ). The decreasing order of performance for the two methodologies regardless of the time scale was: winter, fall, spring and summer.

In general, increasing the time scale improved the performance of the methods, based on $\mathrm{R}^{2}$. It is important to point out that these time scales were generated using a moving average, which decreases the amplitude of the extreme data. 
Table 2. Values of the linear regression coefficients $\beta_{0}$ and $\beta_{1}$, coefficient of determination $\left(R^{2}\right)$ for the regression between reference evapotranspiration (ETo) obtained by PM-FAO method compared to ETo values obtained by PM-FAO methods calculated with missing data and Hargreaves-Samani scores at the two-, four- and seven-day scales at different seasons of the year

\begin{tabular}{|c|c|c|c|c|c|c|c|c|c|c|c|c|c|}
\hline & \multirow{2}{*}{ Method } & \multicolumn{3}{|c|}{ Autumn } & \multicolumn{3}{|c|}{ Winter } & \multicolumn{3}{|c|}{ Spring } & \multicolumn{3}{|c|}{ Summer } \\
\hline & & $\boldsymbol{\beta}_{0}$ & $\beta_{1}$ & $\mathbf{R}^{2}$ & $\beta_{0}$ & $\beta_{1}$ & $\mathbf{R}^{2}$ & $\beta_{0}$ & $\beta_{1}$ & $\mathbf{R}^{2}$ & $\beta_{0}$ & $\beta_{1}$ & $\mathbf{R}^{2}$ \\
\hline \multirow{5}{*}{2 days } & PM-FAO missing RH & 0.15 & 0.94 & 0.83 & 0.32 & 0.89 & 0.76 & 0.17 & 0.92 & 0.66 & 0.10 & 0.95 & 0.94 \\
\hline & PM-FAO missing $\mathrm{R}_{S}$ "Ra" & 0.65 & 0.78 & 0.82 & 0.54 & 0.80 & 0.86 & 2.32 & 0.40 & 0.73 & 2.84 & 0.38 & 0.65 \\
\hline & PM-FAO missing RS "T" & 0.47 & 0.78 & 0.86 & 0.31 & 0.85 & 0.89 & 1.61 & 0.57 & 0.77 & 1.60 & 0.57 & 0.75 \\
\hline & $P M-F A 0$ missing $U_{2}$ & -0.10 & 1.07 & 0.95 & -0.40 & 1.21 & 0.95 & -0.26 & 1.16 & 0.97 & -0.30 & 1.12 & 0.97 \\
\hline & Hargreaves-Samani & 1.11 & 0.79 & 0.59 & 1.19 & 0.78 & 0.61 & 2.31 & 0.58 & 0.59 & 2.57 & 0.55 & 0.63 \\
\hline \multirow{5}{*}{4 days } & PM-FAO missing RH & 0.12 & 0.95 & 0.87 & 0.34 & 0.88 & 0.81 & 0.24 & 0.90 & 0.87 & 0.13 & 0.94 & 0.94 \\
\hline & PM-FAO missing $\mathrm{R}_{\mathrm{S}}$ "Ra" & 0.47 & 0.84 & 0.86 & 0.40 & 0.85 & 0.89 & 2.23 & 0.43 & 0.75 & 2.74 & 0.40 & 0.65 \\
\hline & PM-FAO missing RS "T" & 0.37 & 0.81 & 0.89 & 0.22 & 0.88 & 0.91 & 1.60 & 0.58 & 0.76 & 1.53 & 0.59 & 0.76 \\
\hline & $\mathrm{PM}-\mathrm{FAO}$ missing $\mathrm{U}_{2}$ & -0.06 & 1.06 & 0.96 & -0.38 & 1.20 & 0.96 & -0.25 & 1.16 & 0.97 & -0.25 & 1.11 & 0.97 \\
\hline & Hargreaves-Samani & 0.95 & 0.85 & 0.66 & 1.07 & 0.82 & 0.69 & 2.05 & 0.57 & 0.59 & 2.52 & 0.56 & 0.65 \\
\hline \multirow{5}{*}{7 days } & PM-FAO missing RH & 0.09 & 0.96 & 0.90 & 0.36 & 0.87 & 0.84 & 0.29 & 0.89 & 0.86 & 0.15 & 0.94 & 0.94 \\
\hline & PM-FAO missing $\mathrm{R}_{\mathrm{S}}$ "Ra" & 0.34 & 0.88 & 0.88 & 0.29 & 0.89 & 0.92 & 2.14 & 0.45 & 0.76 & 2.65 & 0.42 & 0.64 \\
\hline & PM-FAO missing RS "T" & 0.31 & 0.84 & 0.91 & 0.15 & 0.91 & 0.93 & 1.56 & 0.58 & 0.75 & 1.46 & 0.60 & 0.76 \\
\hline & PM-FAO missing $U_{2}$ & -0.03 & 1.05 & 0.96 & -0.35 & 1.19 & 0.97 & -0.25 & 1.16 & 0.98 & -0.22 & 1.10 & 0.97 \\
\hline & Hargreaves-Samani & 0.82 & 0.89 & 0.71 & 0.97 & 0.86 & 0.75 & 1.81 & 0.67 & 0.65 & 2.46 & 0.57 & 0.68 \\
\hline
\end{tabular}

RH - Relative humidity; Rs - Solar radiation; Ra - Extraterrestrial solar radiation; $\mathrm{T}$ - Air temperature; $\mathrm{U}_{2}$ - Wind speed

Similar results were found by Bragança et al. (2010), Moura et al. (2013) and Caporusso \& Rolim (2015). The HS method presented poor fit, regardless of the time scale and season (Table 2), which was already verified at the daily scale (Figure $1)$. Based only on these results above $\left(\beta_{0}, \beta_{1}\right.$ and $\left.\mathrm{R}^{2}\right)$, the HS methodology is not recommended for the studied localities. However, other evaluations were done to assess performance.

The performance of the methods was also evaluated using the standard error of estimation (SEE) and the coefficient of performance of Camargo \& Sentelhas (1997) (Table 3). The adoption of $\mathrm{R}^{2}$ as the only criterion for defining the quality of methods is not adequate. The $\mathrm{R}^{2}$ does not establish the type and magnitude of the differences between a standard value and a value predicted by estimation models or other different measurement mechanisms.

The PM-FAO method with missing data of $\mathrm{U}_{2}$ is the best option for estimation of ETo in the northern region of Espírito
Santo in the impossibility of using the standard method. This method performed optimally at all time scales and seasons according to Camargo \& Sentelhas (1997). Lower SEE values for this methodology, which are also lower than the other methodologies in this period, are observed in the autumn, with $0.23,0.20,0.17$ and $0.15 \mathrm{~mm} \mathrm{~d}^{-1}$, for daily, two-, four- and seven-day scales, respectively (Table 3 ).

PM-FAO with missing data of $\mathrm{RH}$ presented a similar result to that of PM-FAO with missing data of $\mathrm{U}_{2}$ according to the classification of Camargo \& Sentelhas (1997), except for the winter performance for the one- and two-day time scales, where its performance was very good, while for $\mathrm{U}_{2}$ it was great. When analyzing the SEE, it was observed that in the spring and summer, PM-FAO missing $\mathrm{U}_{2}$ presented higher values than PM-FAO missing $\mathrm{RH}$, whereas in the autumn and winter the inverse occurred, except in winter on the 7-day scale. This is due to the fact that in spring and summer, wind speeds are

Table 3. Standard error of estimation (SEE) and confidence coefficient (c) obtained by PM-FAO method compared to ETo values obtained by PM-FAO methods calculated with missing data and Hargreaves-Samani scores, for one-, two-, four- and seven-day scales at different seasons of the year

\begin{tabular}{|c|c|c|c|c|c|c|c|c|c|}
\hline & \multirow{2}{*}{ Method } & \multicolumn{2}{|c|}{ Autumn } & \multicolumn{2}{|c|}{ Winter } & \multicolumn{2}{|c|}{ Spring } & \multicolumn{2}{|c|}{ Summer } \\
\hline & & SEE & C & SEE & C & SEE & C & SEE & c \\
\hline \multirow{5}{*}{ Daily } & PM-FAO missing RH & 0.39 & Great & 0.38 & Very good & 0.46 & Great & 0.26 & Great \\
\hline & PM-FAO missing Rs "Ra" & 0.35 & Great & 0.28 & Great & 0.74 & Good & 0.66 & Median \\
\hline & PM-FA0 missing $\mathrm{R}_{\mathrm{S}}$ "T" & 0.35 & Great & 0.26 & Great & 0.61 & Very good & 0.64 & Good \\
\hline & PM-FAO missing $U_{2}$ & 0.23 & Great & 0.28 & Great & 0.48 & Great & 0.35 & Great \\
\hline & Hargreaves-Samani & 0.75 & Median & 0.76 & Poor & 1.00 & Median & 0.79 & Median \\
\hline \multirow{5}{*}{2 days } & PM-FAO missing RH & 0.29 & Great & 0.30 & Very good & 0.39 & Great & 0.24 & Great \\
\hline & PM-FA0 missing $\mathrm{R}_{\mathrm{S}}$ "Ra" & 0.29 & Great & 0.23 & Great & 0.65 & Good & 0.58 & Median \\
\hline & PM-FAO missing $R_{S}$ "T" & 0.31 & Great & 0.22 & Great & 0.53 & Very good & 0.58 & Good \\
\hline & PM-FAO missing $U_{2}$ & 0.20 & Great & 0.26 & Great & 0.45 & Great & 0.33 & Great \\
\hline & Hargreaves-Samani & 0.68 & Median & 0.71 & Median & 0.92 & Median & 0.72 & Median \\
\hline \multirow{5}{*}{4 days } & PM-FA0 missing RH & 0.22 & Great & 0.23 & Great & 0.34 & Great & 0.21 & Great \\
\hline & PM-FAO missing Rs "Ra" & 0.23 & Great & 0.17 & Great & 0.53 & Good & 0.49 & Median \\
\hline & PM-FA0 missing RS "T" & 0.26 & Great & 0.19 & Great & 0.46 & Very good & 0.53 & Good \\
\hline & PM-FAO missing $U_{2}$ & 0.17 & Great & 0.23 & Great & 0.42 & Great & 0.31 & Great \\
\hline & Hargreaves-Samani & 0.63 & Good & 0.66 & Median & 0.86 & Median & 0.66 & Median \\
\hline \multirow{5}{*}{7 days } & PM-FAO missing RH & 0.18 & Great & 0.19 & Great & 0.30 & Great & 0.20 & Great \\
\hline & PM-FA0 missing Rs "Ra" & 0.19 & Great & 0.13 & Great & 0.45 & Good & 0.42 & Good \\
\hline & PM-FAO missing $\mathrm{R}_{\mathrm{S}}$ "T" & 0.23 & Great & 0.17 & Great & 0.40 & Very good & 0.49 & Good \\
\hline & PM-FAO missing $\mathrm{U}_{2}$ & 0.15 & Great & 0.21 & Great & 0.40 & Great & 0.29 & Great \\
\hline & Hargreaves-Samani & 0.59 & Good & 0.64 & Median & 0.82 & Good & 0.62 & Median \\
\hline
\end{tabular}

RH - Relative humidity; Rs - Solar radiation; Ra - Extraterrestrial solar radiation; $T$ - Air temperature; $U_{2}$ - Wind speed 
more influential on ETo, whereas in autumn and winter the $\mathrm{RH}$ is more influential.

The methodologies proposed to estimate the absence of solar radiation, obtained excellent performance in the autumn and winter seasons, regardless of the time scale, with very close SEE values (Table 3). For the other seasons, the optimum performance was not observed. In the winter season, these methodologies presented the lowest values of SEE, mainly on the 7-day scale with 0.13 and $0.17 \mathrm{~mm} \mathrm{~d}^{-1}$, for PM-FAO missing Rs "Ra" and PM-FAO missing “ $\mathrm{T}$ ” Rs, respectively. Thus, these methodologies can be recommended in the region in such period.

These results allow to place the PM-FAO with missing data of relative humidity or wind speed as better options among the proposed models, due to the optimal performance at more scales and more seasons.

Carvalho et al. (2015), in their study on estimation of reference evapotranspiration from limited meteorological data, concluded that PM-FAO with missing data of $\mathrm{RH}$, followed by $\mathrm{PM}-\mathrm{FAO}$ with missing data of $\mathrm{U}^{2}$, is the best alternative to estimate ETo, for Espírito Santo (including the cities of Linhares and São Mateus) and also for Rio de Janeiro. Similar results were also obtained by Morais et al. (2011), for the sub-region of the São Francisco Valley. These authors concluded that the PM-FAO method has good estimates of the ETo values when the absence of data is limited to the variables of relative air humidity and/or wind speed.

The HS method was shown to be a medium-performance method in the classification of Camargo \& Sentelhas (1997), since this classification was repeated 12 times out of a total of 16. In addition, it had a poor classification in the winter, despite a lower SSE than in other combinations (time scale $x$ season), even when they had a median performance. In view of all these pieces of evidence, the HS method should not be used in the studied region in its original form for the time scales.

This low performance of HS is constantly verified in research carried out in regions with different climatic conditions from that in which it was derived, as observed by Cunha et al. (2017) in northwestern Mato Grosso and Alencar et al. (2015) for the state of Minas Gerais, using data from 20 meteorological stations.

However, it should be noted that the temperature-based approaches such as HS have a high potential applicability, among others, because temperature can explain a large amount of ETo variability. In addition, it can easily be measured and is one of the inputs available (Martí et al., 2015).

\section{Conchusions}

1. Penman-Monteith method with missing wind speed data was the one that obtained the best performance for all seasons and time scales.

2. The Penman-Monteith method with missing relative humidity data in the summer at all time scales is a good option.

3. The Hargreaves-Samani method did not present satisfactory performance, with $\mathrm{R}^{2}$ below 0.7 , regardless of the time scale and time of the year, and it yielded the greatest standard error of estimation $\left(1.00 \mathrm{~mm} \mathrm{~d}^{-1}\right)$ at spring on a twoday scale. Thus, its use in the northern region of the Espírito Santo state should be avoided.

4. Penman-Monteith methods with missing solar radiation data are good options for the fall and winter seasons at the four- and seven-day scales.

\section{ACKNOWLedgments}

The authors would like to express gratitude to the Instituto Nacional de Meteorologia - INMET for the access to various datasets and the Brazilian National Council for Scientific and Technological Development (CNPq) for providing scholarship to the first author. This study was financed in part by the Coordenação de Aperfeiçoamento de Pessoal de Nível Superior - Brazil (CAPES) - Finance Code 001.

\section{Literature Cited}

Alencar, L. P.; Sediyama, G. C.; Mantovani, E. C. Estimativa da evapotranspiração de referência ( $\mathrm{ET}_{\mathrm{o}}$ padrão $\mathrm{FAO}$ ), para Minas Gerais, na ausência de alguns dados climáticos. Engenharia Agrícola, v.35, p.39-50, 2015. https://doi.org/10.1590/1809-4430Eng.Agric.v35n1p39-50/2015

Allen, R. G.; Pereira, L. S.; Raes, D.; Smith, M. Crop evapotranspiration: Guidelines for computing crop water requirements. Rome: FAO, 1998. 300p.

Alvares, C. A.; Stape, J. L.; Sentelhas, P. C.; Gonçalves, J. L. de M.; Sparovek, G. Köppen's climate classification map for Brazil. Meteorologische Zeitschrift, v.22, p.711-728, 2013. https://doi. org/10.1127/0941-2948/2013/0507

Arraes, F. D. D.; Lima Júnior, J. C.; Oliveira, J. B. de; Macêdo, K. G. de; Couras, Y. de S.; Oliveira, W. C. de. Parametrização da equação de Hargreaves-Samani para o estado do Pernambuco - Brasil. Revista Brasileira de Agricultura Irrigada, v.10, p.410-419, 2016. https://doi.org/10.7127/rbai.v10n100369

Borges Júnior, J. C. F.; Oliveira, A. L. M.; Andrade, C. de L. T. de; Pinheiro, M. A. B. Equação de Hargreaves-Samani calibrada em diferentes bases temporais para Sete Lagoas, MG. Engenharia na Agricultura, v.25, p.38-49, 2017.

Bragança, R.; Reis, E. F. dos; Garcia, G. de O.; Pezzopane, J. E. M. Estudo comparativo da evapotranspiração de referência no período chuvoso para três localidades no estado do Espírito Santo. Idesia, v.28, p.21-29, 2010. https://doi.org/10.4067/S071834292010000200003

Čadro, S.; Uzunović, M.; Žurovec, J.; Žurovec, O. Validation and calibration of various reference evapotranspiration alternative methods under Bosnia and Herzegovina climate conditions. International Soil and Water Conservation Research, v.5, p.309324, 2017. https://doi.org/10.1016/j.iswcr.2017.07.002

Camargo, A. P.; Sentelhas, P. C. Avaliação do desempenho de diferentes métodos de estimativa da evapotranspiração potencial no estado de São Paulo, Brasil. Revista Brasileira de Agrometeorologia, v.5, p.89-97, 1997.

Caporusso, N. B.; Rolim, G. de S. Reference evapotranspiration models using different time scales in the Jaboticabal region of São Paulo, Brazil. Acta Scientiarum. Agronomy, v.37, p.1-9, 2015. https:// doi.org/10.4025/actasciagron.v37i1.18277 
Carvalho, D. F. de; Rocha, H. S. da; Bonomo, R.; Souza, A. P. de. Estimativa da evapotranspiração de referência a partir de dados meteorológicos limitados. Pesquisa Agropecuária Brasileira, v.50, p.1-11, 2015. https://doi.org/10.1590/S0100-204X2015000100001

Cunha, F. F. da; Venancio, L. P.; Campos, F. B.; Sediyama, G. C. Reference evapotranspiration estimates by means of HargreavesSamani and Penman-Monteith FAO methods with missing data in the northwestern Mato Grosso do Sul. Bioscience Journal, v.33, p.1166-1176, 2017. https://doi.org/10.14393/BJv33n5a2017-36751

Feng, Y.; Jia, Y.; Cui, N.; Zhao, L.; Li, C.; Gong, D. Calibration of Hargreaves model for reference evapotranspiration estimation in Sichuan basin of southwest China. Agricultural Water Management, v.181, p.1-9, 2017. https://doi.org/10.1016/j.agwat.2016.11.010

Fernandes, D. S.; Heinemann, A. B.; Paz, R. L. F.; Amorim, A. de O. Calibração regional e local da equação de Hargreaves para estimativa da evapotranspiração de referência. Revista Ciência Agronômica, v.43, p.246-255, 2012. https://doi.org/10.1590/ S1806-66902012000200006

Gavilán, P.; Lorite, I. J.; Tornero, S.; Berengena, J. Regional calibration of Hargreaves equation for estimating reference ET in a semiarid environment. Agricultural Water Management, v.81, p.257-281, 2006. https://doi.org/10.1016/j.agwat.2005.05.001

Gocic, M.; Trajkovic, S. Software for estimating reference evapotranspiration using limited weather data. Computers and Electronics in Agriculture, v.71, p.158-162, 2010. https://doi. org/10.1016/j.compag.2010.01.003

Hargreaves, G. H.; Samani, Z. A. Reference crop evapotranspiration from temperature. Applied Engineering in Agriculture, v.1, p.9699, 1985. https://doi.org/10.13031/2013.26773

Hou, L.; Zou, S.; Xiao, H.; Yang, Y. Sensitivity of the reference evapotranspiration to key climatic variables during the growing season in the Ejina oasis northwest China. Springer Plus, v.2, p.1-6, 2013. https://doi.org/10.1186/2193-1801-2-S1-S4

Lemos Filho, L. C. A.; Carvalho, L. G.; Evangelista, A. W. P.; Alves Júnior, J. Análise espacial da influência dos elementos meteorológicos sobre a evapotranspiração de referência em Minas Gerais. Revista Brasileira de Engenharia Agrícola e Ambiental, v.14, p.1294-1303, 2010. https://doi.org/10.1590/ S1415-43662010001200007
Lima Júnior, J. C. de; Arraes, F. D. D.; Oliveira, J. B. de; Nascimento, F. A. L. do; Macêdo, K. G. de. Parametrização da equação de Hargreaves e Samani para estimativa da evapotranspiração de referência no Estado do Ceará, Brasil. Revista Ciência Agronômica, v.47, p.447-454, 2016. https://doi.org/10.5935/18066690.20160054

Martí, P.; Zarzo, M.; Vanderlinden, K.; Girona, J. Parametric expressions for the adjusted Hargreaves coefficient in Eastern Spain. Journal of Hydrology, v.529, p.1713-1724, 2015. https:// doi.org/10.1016/j.jhydrol.2015.07.054

Morais, J. E. F. de; Silva, T. G. F. da; Souza, L. S. B. de; Moura, M. S. B. de; Diniz, W. J. da S.; Souza, C. A. A. de. Avaliação do método de Penman Monteith FAO 56 com dados faltosos e de métodos alternativos na estimativa da evapotranspiração de referência no Submédio Vale do São Francisco. Revista Brasileira de Geografia Física, v.8, p.1644-1660, 2011.

Moura, A. R. C.; Montenegro, S. M. G. L.; Antonino, A. C. D.; Azevedo, J. R. G. de; Silva, B. B. da; Oliveira, L. M. M. de. Evapotranspiração de referência baseada em métodos empíricos em bacia experimental no Estado de Pernambuco - Brasil. Revista Brasileira de Meteorologia, v.28, p.181-191, 2013. https://doi. org/10.1590/S0102-77862013000200007

Sentelhas, P. C.; Gillespie, T. J.; Santos, E. A. Evaluation of FAO Penman-Monteith and alternative methods for estimating reference evapotranspiration with missing data in Southern Ontario, Canada. Agricultural Water Management, v.97, p.635644, 2010. https://doi.org/10.1016/j.agwat.2009.12.001

Silva, B. K. N.; Silva, V. de P. R.; Azevedo, P. V. de; Farias, C. H. de A. Análise de sensibilidade dos métodos de estimativa da evapotranspiração de referência e razão de Bowen em cultura da cana-de-açúcar. Revista Brasileira de Engenharia Agrícola e Ambiental, v.15, p.1046-1053, 2011. https://doi.org/10.1590/ S1415-43662011001000008

Tabari, H.; Talaee, P. H. Local calibration of the Hargreaves and Priestley-Taylor equations for estimating reference evapotranspiration in arid and cold climates of Iran based on the Penman-Monteith model. Journal of Hydrologic Engineering, v.16, p.837-845, 2011. https://doi.org/10.1061/(ASCE)HE.19435584.0000366 